\title{
Studying the tendency of citizens to participate in the protection and development of land scape in Tehran
}

\author{
Shadi Maleki, Abbas Mafi, Seyedeh Mahsa Hosseini* \\ Research, training and consultancy of landscape, Municipality of Tehran, District4, Tehran, Iran \\ *Corresponding Author
}

\begin{abstract}
Today, as an essential part and parcel of urban landscape that they play a major role in metabolism and create a lack of serious damage to urban life. This study performed to investigate the willingness of citizens to participate in activities to protect and develop landscapeof Tehran district 4. The research was descriptive and correlation method that is used for collecting information. The statistical population consisted of district 4 of Tehran. The sample size was determined 230 by using Cochrane method. A questionnaire was used to collect data. According to the research, 63.04 percent of citizens showed participation in a high level. Among the variables investigated how citizen participation in conservation and development of landscape, effective strategies to motivate citizens to participate, the reasons for lack of cooperation and participation of citizens learn about gardening and landscaping, introductory training centers with the desire of citizens to participate in municipal plants open landscape had a significant relationship and stepwise regression analysis results showed that four variableseffective strategies to motivate citizens to participate, method to involve citizens in the landscape, the reasons for lack of cooperation and participation of citizens familiar with gardening and landscaping activities have on the willingness of citizens to participate effectively.
\end{abstract}

Keywords - Tehran, urban environment, Landscape.

\section{INTRODUCTION}

In recent years, urbanization has always experienced ever increasing growth. The last decades $100 \%$ increase in urban population,comprising about $45 \%$ of the world population. Besides advantages such as accessibility to clean water and so like, the negative effects of urbanization on environment, especially degradation and pollution of urban environment cannot be ignored (Zare et al., 2009).

Significant expansion of urbanization in recent years, especially population growth in large cities like Tehran, has left many problems, So that urban management in big cities will not be able to solve this problem with traditional and last common methods (Asghar pour, 2006).Today urban activities will ensure the development and efficiency of urban services, (Rezaee, 1996)Considering the fact that the future of human life depends on the protection of nature and environment resources, Therefore, to provide an advanced understanding of the nature is effective for change in the attitude of public, Experience in managing cities of different countries shows that well-managed cities is out of government power in many cases, Success in this regard depends on the participation of people and local institutionsAnd only with the public trust, encourage people in different stages of public consultation will lead to a largely urban management successfully.Social participation of citizens in the city management led to increasing social cooperation;On the other hand the lack of citizen participation in city management will create negative consequences for urban management. Tehran is the eighteenth most populous city in the world, Tehran's air pollution is one of the main problems of the metropolis. Natural factors, forms of urban construction, cars and vehicles, factories and industrial plants and ... led to pollution of city as one of the world's most polluted cities. So that after New Delhi was the world's most polluted city (Riahi Moghadam, 2012), these factors, in addition to the problem of shortage of land for green space development, will impose heavy costs for urban management (Shafiee, 2006).Therefore study citizens' willingness to develop and maintain urban green space is importantand that without understanding the factors affecting the willingness of citizens are not allowed to participate. Shiani (2010) have done a project called "design patterns of citizen involvement in Tehran", He stated the best way of public participation in city affairs organized formal and planned models are for the larger cities and grassroots models for smaller cities, Shafiee (2006) reported that Background participation, understanding the concept of participation, sense of 
belonging to the residence, assessing the consequences of participation, profit contribution activities, leisure, social trust people together, inform and respond urban managers, traditionalism, a sense of social belonging, a sense of ownership urban environment, satisfaction with municipal services, the municipality's sense of empowerment, a sense of the effectiveness of citizenship, social status, economic and social membership are that explainparticipation. In all studies, the rate of participation in municipal affairs were mostly moderate, the results of Ries (2004) showed government attention to public education, citizen participation and proper planning and management are the most important factors promoting partnership programs. The aim of this study was to Studying the tendency of citizens to participate in the protection and development of land scape in Tehran, distric4.

\section{MATERIAL AND METHODS}

The statistical population included all citizens of district 4 of Tehran, The sample size (230 person) was determined using the Cochran, investigated Samples were citizens to take advantage of green space and park facilities located in the district 4 of Tehran. Selected parks were located from all district4. Data were collected through interviews with citizens; the questionnaire was used to collect data and it included attitude and willingness of citizens to participate as dependent variable, General characteristics of the individual and citizen, , methods of citizen participation in conservation and development of green space, Effective strategies to motivate and willingness of citizens to participate, The reasons for lack of cooperation and participation of citizens in the administration of green spaces as independent variables. Independent variables in a five-point Likert scale was measured from very low to very high. Distance and nominal scales were used to measure individual and public characteristics,

The validity of questionnaires confirmed by extension and education of agricultural and experts of Tehran municipal green space, Also Reliability was approved through Cronbach's alpha coefficient in the range of 0.81- 0.91, Data analyzed by using SPSS software. Some parameters were determined such as descriptive statistics (frequency, percentage, mean, standard deviation, coefficient of variation) and inferential statistics (Pearson correlation, multiple regression and compare group means and test $(\mathrm{T}$ and F).

Table.1: levels, dimensions, number of questions and different parts of the questionnaire Cronbach's alpha coefficient

\begin{tabular}{lll}
\hline & $\begin{array}{c}\text { Number } \\
\text { questions }\end{array}$ & $\begin{array}{c}\text { of Cronbach's } \\
\text { coefficients }\end{array}$ \\
\hline $\begin{array}{l}\text { Attitude and willingness of citizens to participate in the protection and } \\
\text { development of green space }\end{array}$ & 0.82 \\
method of citizen participation in conservation and development of green & 4 & 0.83 \\
spaces & & 0.81 \\
$\begin{array}{l}\text { Effective strategies to motivate and willingness of citizens to participate } \\
\text { The reasons for lack of cooperation and participation of citizens in the }\end{array}$ & 4 & 0.91 \\
administration of green spaces & & 0.84 \\
\hline means & 20 & \\
\hline
\end{tabular}

\section{RESULTS AND DISCUSSION}

Individual and public features of respondents

Citizens who participated in this research included $65.70 \%$ female and $34.30 \%$ male that single and married were 19.10 and $90.90 \%$ respectively. Findings from the study showed that the average age of respondents was 38.7 old years, also oldest and the youngest of them were 72 and 18 years old, respectively.It can be concluded that among the studied citizens, adults and middle-aged people are more willing to contribute to the maintenance and development of green space.13.5\% and $50.4 \%$ of respondents had under diploma education and diploma education, respectively and 36.10 percent had a college degree.Job status of respondents included $29.1 \%$ housekeeper, $3.5 \%$ students, $14.2 \%$ employees, $23 \%$ retired and 30\% self-employed.The information rate of respondents from agricultural activity and green space included $59.6 \%$ low information, $32.2 \%$ moderate information, $8.30 \%$ high information. The majority of citizens $(72.6 \%)$ say know Nature Day, also $74.8 \%$ of respondents had knowledge about the role of green spaces in urban life, 27.4, 31.3 and $41.3 \%$ of respondents had high, moderate and low information about municipal education and counseling centers of flowers and Plants, respectively.

\section{Ranking items related to the main variables}

The results are presented in Table 2, 63.04, 20.87 and 16.09 percent of respondents have a high, moderate and low willingness to contribute to the protection and development of urban green space. On method of citizen 
participation in preserving green space, ranking of items showed that people had highest participate in the design, construction and maintenance of green spaces and cultural and reminded the citizens to prevent the destruction of green space, gathering and transmission of comments, suggestions and complaints to municipal volunteers. This result was in order with Khorasani and Pour Asad (2003) results.

Table.2:Ranking items related to the attitudes of citizens to participate in the preservation and expansion of green areas

\begin{tabular}{lllll}
\hline & Mean & $\begin{array}{l}\text { Standard } \\
\text { deviation }\end{array}$ & $\begin{array}{l}\text { Coefficient } \\
\text { variation }\end{array}$ & of \\
\hline $\begin{array}{l}\text { A sense of responsibility in the maintenance and development of } \\
\text { green space }\end{array}$ & 4.01 & 1.27 & 0.31 & 1 \\
$\begin{array}{l}\text { Participation and cooperation with the municipality to maintain } \\
\text { and expand of green space }\end{array}$ & 3.80 & 1.3 & 0.34 & 2 \\
$\begin{array}{l}\text { Interest in learning and understanding the operating activities of } \\
\text { green space }\end{array}$ & & 1.71 & 0.37 & 4 \\
$\begin{array}{l}\text { Usefulness of classes and educational programs related to } 3.0 \\
\text { landscape }\end{array}$ & 1.17 & 0.39 & 4 \\
\hline
\end{tabular}

Table.3: Frequency distribution of participants according to the desire of citizens to participate in the preservation and expansion of green areas

\begin{tabular}{llll}
\hline Willingness to participate & frequency & percentage & cumulative percentage \\
\hline \multicolumn{1}{c}{ week } & 37 & 16.09 & 16.09 \\
moderate & 48 & 20.87 & 36.96 \\
good & 57 & 24.87 & 61.74 \\
excellent & 88 & 38.26 & 100 \\
sum & & 100 & \\
\hline
\end{tabular}

Table.4: Ranking items related to how and method of citizen participation in preserving green space

\begin{tabular}{|c|c|c|c|c|}
\hline & Mean & $\begin{array}{l}\text { Standard } \\
\text { deviation }\end{array}$ & $\begin{array}{l}\text { Coefficient of } \\
\text { variation }\end{array}$ & rank \\
\hline Design, construction and maintenance of green spaces & 3.98 & 1.43 & 0.35 & 1 \\
\hline $\begin{array}{l}\text { warning the citizens to prevent the destruction of green } \\
\text { space }\end{array}$ & 3.6 & 1.42 & 0.39 & 2 \\
\hline $\begin{array}{l}\text { Collecting and transmitting comments, suggestions and } \\
\text { complaints to municipal volunteers }\end{array}$ & 3.43 & 1.38 & 0.40 & 3 \\
\hline $\begin{array}{l}\text { nforming and educating the citizens about the } \\
\text { importance of green space }\end{array}$ & 3.20 & 1.44 & 0.45 & 4 \\
\hline
\end{tabular}

Result of effective strategies to motivate and willingness of citizens to participate in the development of green spaces showed that Citizens believe the municipality has set up a free inspection centers of plants and unique parks in the city,Giving a discount on payment of annual municipal facilities and for active citizenship, Free donating plants and agricultural inputs, Awards and introducing active citizens in a special ceremonycan provide field to motivate and attendancein order to contribute to the preservation and development of green spaces in Tehran. In relation to reasons for the lack of cooperation and participation of citizens in the preservation and development of urban green space, Restrictions on cultural and traditional barriers, Lack of awareness and knowledge of the importance of urban green space,the lack of incentives to encourage citizens obtained as main reasons for non-participation and cooperation of citizens. Alavi Tabar (2000) and Sadeghi (2005), Abdillahi and Shiani (2008)reported similar results. 
Table.5: Ranking items related to effective strategies to motivate and willingness of citizens to participate in

\begin{tabular}{|c|c|c|c|c|}
\hline & Mean & $\begin{array}{l}\text { Standard } \\
\text { deviation }\end{array}$ & $\begin{array}{l}\text { Coefficient of } \\
\text { variation }\end{array}$ & rank \\
\hline $\begin{array}{l}\text { set up a free inspection centers of plants and unique } \\
\text { parks in the city }\end{array}$ & 4.08 & 0.82 & 0.20 & 1 \\
\hline $\begin{array}{l}\text { Giving a discount on payment of annual municipal } \\
\text { facilities and for active citizenship }\end{array}$ & 4.00 & 1.26 & 0.31 & 2 \\
\hline Free donating plants and agricultural inputs & 3.99 & 1.28 & 0.32 & 3 \\
\hline $\begin{array}{l}\text { Awards and introducing active citizens in a special } \\
\text { ceremony }\end{array}$ & 3.92 & 1.31 & 0.33 & 4 \\
\hline training courses related to green space & 3.50 & 1.36 & 0.38 & 5 \\
\hline Issuing ID cards to members & 2.94 & 1.07 & 0.36 & 6 \\
\hline Special clothing for members & 2.86 & 1.14 & 0.39 & 7 \\
\hline Donate books and educational and cultural products & 2.77 & 1.19 & 0.42 & 8 \\
\hline
\end{tabular}

Table.6: Ranking items related to lack of cooperation and participation of citizens in the preservation and development of urban green space

\begin{tabular}{|c|c|c|c|c|}
\hline & Mean & $\begin{array}{l}\text { Standard } \\
\text { deviation }\end{array}$ & $\begin{array}{l}\text { Coefficient of } \\
\text { variation }\end{array}$ & rank \\
\hline Restrictions on cultural and traditional barriers & 3.76 & 1.24 & 0.32 & 1 \\
\hline $\begin{array}{l}\text { Lack of awareness and knowledge of the importance of } \\
\text { urban green space }\end{array}$ & 3.80 & 1.28 & 0.33 & 2 \\
\hline the lack of incentives to encourage citizens & 3.76 & 1.48 & 0.39 & 3 \\
\hline $\begin{array}{l}\text { Lack of support and attention to the views and interests } \\
\text { of citizens in urban green space }\end{array}$ & 3.64 & 1.47 & 0.40 & 4 \\
\hline
\end{tabular}

\section{The relationship between variables}

Results showed that 4 introduced variables to equation included Effective strategies to motivate and willingness of citizens to participate, method of citizen participation in

Table.7: Correlation between studied variables with Willingness to participate in the preservation and expansion of green areas

\begin{tabular}{ll}
\hline method of citizen participation in conservation and development of green spaces & $0.329^{* *}$ \\
Effective strategies to motivate and willingness of citizens to participate & $0.769^{* *}$ \\
The reasons for lack of cooperation and participation of citizens & $0.512^{* *}$ \\
Learn about gardening and landscaping & $0.190^{* *}$ \\
Level of Education & 0.124 \\
Familiarity with Flowers and Plants training and consulting centers of Municipal & $0.166^{*}$ \\
Age & 0.031
\end{tabular}

*and** show significant levels at 5 and 1\%

Table.8: Result of Stepwise multiple regression

\begin{tabular}{|c|c|c|c|c|}
\hline & B & Beta & $\mathrm{T}$ & Sig. \\
\hline Constant & -0.871 & --- & -3.941 & 0.000 \\
\hline $\begin{array}{l}\text { Effective strategies to motivate and willingness of citizens to } \\
\text { participate }(\mathrm{x} 1)\end{array}$ & 0.854 & 0.690 & 14.995 & 0.000 \\
\hline $\begin{array}{l}\text { method of citizen participation in conservation and development of } \\
\text { green spaces }(\mathrm{x} 2)\end{array}$ & 0.198 & 0.234 & 5.993 & 0.000 \\
\hline The reasons for lack of cooperation and participation of citizens(x3) & 0.093 & 0.117 & 2.549 & 0.009 \\
\hline Introduction to agricultural activity and green space (x4) & 0.09 & 0.089 & 2.244 & 0.008 \\
\hline
\end{tabular}


$\mathrm{Y}=-0.871+0.854 \mathrm{X}_{1}+0.198 \mathrm{X}_{2}-0.093 \mathrm{X}_{3}+0.090 \mathrm{X}_{4}$

\section{Compare between group means}

According to $\mathrm{t}$ test analysis, there were no significant differences between male and female, also single and married (table 9 and 10). Citizens that had information about the role of landscape in urban life and Nature Day so, they were more willing to participate (table 11).In this order, Khorasani and pour Asad (2003) reported similar result but Behzad et al (2010) male had higher willingness in compare to female.

Table.9: Compare female and male for the willingness of participate in the maintenance and development of green space

\begin{tabular}{llllll}
\hline & & means & Standard deviation & t-test & P-value \\
\hline Female & 151 & 13.71 & 3.76 & 1.02 & 0.309 \\
Male & 79 & 13.16 & 4.10 & & \\
\hline
\end{tabular}

Table.10: Compare single and married for the willingness of participate in the maintenance and development

\begin{tabular}{llllll}
\multicolumn{7}{c}{ of green space } \\
\hline single & 44 & means & Standard deviation & t-test & P-value \\
married & 186 & 14.15 & 3.46 & 1.202 & 0.231
\end{tabular}

\section{CONCLUSION}

According to the research, 63.04 percent of citizens showed participation in a high level. Among the variables investigated how citizen participation in conservation and development of landscape, effective strategies to motivate citizens to participate, the reasons for lack of cooperation and participation of citizens learn about gardening and landscaping, introductory training centers with the desire of citizens to participate in municipal plants open landscape had a significant relationship and stepwise regression analysis results showed that four variables effective strategies to motivate citizens to participate, method to involve citizens in the landscape, the reasons for lack of cooperation and participation of citizens familiar with gardening and landscaping activities have on the willingness of citizens to participate effectively.

\section{REFERENCES}

[1] Alavi Tabar, A. (2000).The pattern of citizen participation in city affairs (global experiences and Iran). Organization of municipalities(In Persian)

[2] Asghar pour A. (2006). Strategies to increase citizens' participation.Research projects, Research Center of Mashhad City (In Persian)

[3] Behzad, N. (2010). The role of communityparticipation in the development of urban greenspaces. garden news,14(6),50-57 Retrieved from:http://artahort.blogsky.com.

[4] Khorasani, N., Pour Asad, K, (2003). The role of public participation in preservation, maintenance and development of parks in Tehran and presenting suitable solutions (Case study, 13 Aban alley),
Environmental Science and Technology, 17(3), 125132.

[5] Rezaee, A. (2006). Social participation, goal or development tools. Political \& Economic Journal, 110: 201-209 (In Persian)

[6] Riahee Moghadam, S. (2012).Management of city perspective.Perspective journal 18: 4-9(In Persian)

[7] Ries, D .(2004).Urban and community forestryin Oregon: Results of the 2004 city survey,Journal of Socio-Economics, 28(3), 335-349.

[8] Sadeghi, M. (2005).Restoring the urban parks. Master's thesis, Tehran University(In Persian)

[9] Shafiee, S. (2006). Sociological surveys of factors affecting social participation of citizens in Ardabil. Thesis for Master of Social Science degree, Azad University, Roodehen Branch(In Persian)

[10] Shiani, M. (2008). Citizenship status and obstacles to its realization in Iran. PhD thesis in sociology of Tehran. Allameh Tabatabaei University(In Persian)

[11]Zare, S., Namiranian, M., \& Fami, H. (2009). Factors influencing intention toward participation in administration and protection of forest parks in Tehran, Journal of Forest, 1(3), 197-208. (In Persian). 